\title{
Twenty-seven-year time trends in dementia incidence in Europe and the United States
}

\author{
The Alzheimer Cohorts Consortium
}

Frank J. Wolters, MD, PhD, * Lori B. Chibnik, PhD, MPH, ${ }^{\star}$ Reem Waziry, MD, PhD, Roy Anderson, FRS, FMedSci, Claudine Berr, MD, PhD, Alexa Beiser, PhD, Joshua C. Bis, PhD, Deborah Blacker, MD, ScD,

Daniel Bos, MD, PhD, Carol Brayne, MD, Jean-François Dartigues, MD, PhD, Sirwan K.L. Darweesh, MD, PhD, Kendra L. Davis-Plourde, MA, Frank de Wolf, MD, PhD, Stephanie Debette, PhD, Carole Dufouil, PhD, Myriam Fornage, PhD, Jaap Goudsmit, MD, PhD, Leslie Grasset, PhD, Vilmundur Gudnason, MD, PhD, Christoforos Hadjichrysanthou, PhD, Catherine Helmer, MD, PhD, M. Arfan Ikram, MD, PhD, M. Kamran Ikram, MD, PhD, Erik Joas, PhD, Silke Kern, MD, Lewis H. Kuller, MD, DrPH, Lenore Launer, PhD, Oscar L. Lopez, MD, PhD, Fiona E. Matthews, PhD, Kevin McRae-McKee, MSc, Osorio Meirelles, PhD, Thomas H. Mosley, Jr., PhD, Matthew P. Pase, PhD, Bruce M. Psaty, MD, PhD, Claudia L. Satizabal, PhD, Sudha Seshadri, MD, DM, Ingmar Skoog, MD, PhD, Blossom C.M. Stephan, PhD, Hanna Wetterberg, MSc, Mei Mei Wong, PhD, Anna Zettergren, PhD, and Albert Hofman, MD, PhD

Neurology ${ }^{\circledR}$ 2020;95:e519-e531. doi:10.1212/WNL.0000000000010022

\section{Abstract}

\section{Objective}

To determine changes in the incidence of dementia between 1988 and 2015.

\section{Methods}

This analysis was performed in aggregated data from individuals $>65$ years of age in 7 population-based cohort studies in the United States and Europe from the Alzheimer Cohort Consortium. First, we calculated age- and sex-specific incidence rates for all-cause dementia, and then defined nonoverlapping 5-year epochs within each study to determine trends in incidence. Estimates of change per 10-year interval were pooled and results are presented combined and stratified by sex.

\section{Results}

Of 49,202 individuals, 4,253 (8.6\%) developed dementia. The incidence rate of dementia increased with age, similarly for women and men, ranging from about 4 per 1,000 person-years in individuals aged 65-69 years to 65 per 1,000 person-years for those aged $85-89$ years. The incidence rate of dementia declined by $13 \%$ per calendar decade ( $95 \%$ confidence interval [CI], $7 \%-19 \%)$, consistently across studies, and somewhat more pronouncedly in men than in women (24\% [95\% CI 14\%-32\%] vs $8 \%$ [0\%-15\%]).

\author{
Correspondence \\ Dr. Hofman \\ ahofman@hsph.harvard.edu
}

\footnotetext{
*These authors contributed equally to this work.

From the Department of Epidemiology (F.J.W., L.B.C., R.W., D. Blacker, D. Bos, J.G., A.H.), Harvard T.H. Chan School of Public Health, Boston, MA; Departments of Epidemiology (F.J.W., D. Bos, S.K.L.D., M.A.I., M.K.I., A.H.), Radiology and Nuclear Medicine (D. Bos), and Neurology (M.K.I.), Erasmus MC, Rotterdam, the Netherlands; Department of Neurology (L.B.C.), Massachusetts General Hospital, Boston; Department of Infectious Disease Epidemiology (R.A., F.d.W., C. Hadjichrysanthou, K.M.-M., M.M.W.), School of Public Health, Imperial College London, UK; Neuropsychiatry and Epidemiology and Clinical Research (C. Berr), INSERM, UMR 1061 Montpellier, Universite de Montpellier, France; Boston University School of Medicine (A.B., M.P.P., C.L.S., S.S.); Framingham Heart Study (A.B., M.P.P., C.L.S., S.S.), MA; Department of Biostatistics (A.B., K.L.D.-P.), Boston University School of Public Health, MA; Cardiovascular Health Research Unit, Departments of Medicine (J.C.B., B.M.P.) and Epidemiology and Health Services (B.M.P.), University of Washington, Seattle; Department of Psychiatry (D. Blacker), Massachusetts General Hospital, Charlestown; University of Cambridge (C. Brayne), UK; Bordeaux Population Health Research Center (J.-F.D., S.D., C.D., L.G., C. Helmer), INSERM, UMR 1219, University of Bordeaux; Department of Neurology (S.D.), Memory Clinic, Bordeaux University Hospital, France; McGovern Medical School (M.F.), University of Texas Health Science Center at Houston; Icelandic Heart Association (V.G.), Kopavogur; Faculty of Medicine (V.G.), University of Iceland, Reykjavik; Institute of Neuroscience and Physiology (E.J., S.K., I.S., H.W., A.Z.), Sahlgrenska Academy, University of Gothenburg, Sweden; Department of Epidemiology, Graduate School of Public Health (L.H.K.), and Departments of Neurology and Psychiatry (O.L.L.), University of Pittsburgh, PA; Laboratory of Epidemiology and Population Sciences (L.L., O.M.), National Institute on Aging, Bethesda, MD; Institute of Health and Society (F.E.M., B.C.M.S.), Newcastle University, Newcastle upon Tyne, UK; MIND Center (T.H.M.), University of Mississippi Medical Center, Jackson; Melbourne Dementia Research Centre (M.P.P.), The Florey Institute for Neuroscience and Mental Health, Melbourne, Australia; Kaiser Permanente Washington Health Research Institute (B.M.P.), Seattle; and The Glenn Biggs Institute for Alzheimer's \& Neurodegenerative Diseases (C.L.S., S.S.), UT Health San Antonio, TX.
}

Go to Neurology.org/N for full disclosures. Funding information and disclosures deemed relevant by the authors, if any, are provided at the end of the article.

The Article Processing Charge was funded by Association of Universities in the Netherlands (VSNU) Association of Universities in the Netherlands (VSNU).

This is an open access article distributed under the terms of the Creative Commons Attribution-NonCommercial-NoDerivatives License 4.0 (CC BY-NC-ND), which permits downloading

and sharing the work provided it is properly cited. The work cannot be changed in any way or used commercially without permission from the journal. 


\section{Glossary}

3C $=$ Three-City Study; ACC = Alzheimer Cohorts Consortium; AD = Alzheimer disease AGES-Reykjavik Study = Age, Gene/Environment Susceptibility-Reykjavik Study; ARIC = Atherosclerosis Risk in Communities; CFAS = Cognitive Function and Ageing Studies; CHS = Cardiovascular Health Study; CI = confidence interval; DSM-III-R = Diagnostic and Statistical Manual of Mental Disorders, 3rd edition, revised; DSM-IV = Diagnostic and Statistical Manual of Mental Disorders, 4th edition; FHS = Framingham Heart Study; HR = hazard ratio; IR = incidence rate; PAQUID = Personnes Agées QUID; RS = Rotterdam Study.

\section{Conclusion}

The incidence rate of dementia in Europe and North America has declined by $13 \%$ per decade over the past 25 years, consistently across studies. Incidence is similar for men and women, although declines were somewhat more profound in men. These observations call for sustained efforts to finding the causes for this decline, as well as determining their validity in geographically and ethnically diverse populations.

An estimated 47 million people worldwide are living with dementia, making it a leading cause of dependence and disability. ${ }^{1-3}$ Because of rapid aging of the population, the number of people living with dementia is projected to triple in the next 30 years, and the socioeconomic burden of dementia to increase accordingly. The projected burden of dementia could be alleviated if improvements in life conditions and health care over the last decades have decreased dementia risk. Indeed, recent studies in North America and Europe have reported a decline in the incidence of dementia over the last 40 years, with possible reductions of $10 \%-38 \%$ per decade, but estimates are inconsistent and often imprecise. ${ }^{4-8}$

Reliable assessment of time trends in the incidence of dementia calls for careful monitoring in the general population, in a consistent manner over a prolonged period of time. Population-based cohort studies have generally collected data on dementia incidence over decades, but few have been designed and powered to test for differences across calendar time. Consequently, individual studies lack the precision to quantify time trends in dementia incidence, leaving projections of the future burden of disease uncertain, with the range of reported reductions in time trends allowing for a variation of tens of millions new cases of dementia in the coming decades. Large heterogeneity, notably in the applied methodology of prior analysis of secular trends, further hinders comparison and reliable prediction across populations. ${ }^{6,9}$ In a multinational collaboration, we aggregated data from available long-term population-based studies from Europe and the United States to study the trend in dementia incidence and establish whether similar changes were observed in men and women.

\section{Methods}

Data sources and study population: Alzheimer Cohorts Consortium (ACC)

The ACC is composed of 9 cohorts selected based on predetermined criteria. Specifically, the included cohorts had to be prospective, population-based, have in-person examinations, a span of at least 15 years of available follow-up, and include at least 2,000 participants at baseline. In addition, many cohorts have data on genotype and extensive phenotyping, particularly of cardiovascular factors and acquisition of brain MRI. The consortium includes the Age, Gene/ Environment Susceptibility (AGES)-Reykjavik Study, the Atherosclerosis Risk in Communities (ARIC) study, the Cardiovascular Health Study (CHS), the Cognitive Function and Ageing Studies (CFAS), the Framingham Heart Study (FHS), the Gothenburg population studies, the Personnes Agées QUID (PAQUID) study, the Rotterdam Study (RS), and the Three-City Study (3C). More detailed information on the ACC has been published previously. ${ }^{10}$

\section{Standard protocol approvals, registrations, and patient consents}

All the participating ACC studies were approved by their respective institutional review committees, and all participants provided written informed consent.

\section{Cohorts}

The present study included 7 participating cohorts (data collection summaries are presented in table 1 ), and include a total of 49,202 (minimum age of 65 at entry) participants, of whom 4,253 had developed dementia to date. Cohort descriptions have been provided previously. ${ }^{8}$ Briefly, the AGES-Reykjavik Study is a sample drawn from the population-based Reykjavik Study cohort. ${ }^{11}$ The original source population in the Reykjavik Study included a random sample of men and women born between 1907 and 1935 and living in Reykjavik in 1967. Between 2002 and 2006, 5,764 survivors of the original cohort were reexamined for the AGES-Reykjavik study. The CFAS comprises 2 population-based studies among individuals aged 65 years and over living in the community, including those in institutions. ${ }^{5}$ The original 6-site study began in 1989 (MRC-CFAS; response 80\%), however, interviewing began in 1991 for the 3 sites that were selected for the current 
Table 1 Demographics and characteristics of cohorts

\begin{tabular}{|c|c|c|c|c|c|c|c|c|}
\hline Study & PAQUID & $\begin{array}{l}\text { Rotterdam } \\
\text { Study }\end{array}$ & $\begin{array}{l}\text { Framingham Heart } \\
\text { Study }\end{array}$ & $\begin{array}{l}\text { Gothenburg } \\
\text { studies }\end{array}$ & CFAS I & $\begin{array}{l}\text { CFAS } \\
\text { II }\end{array}$ & $\begin{array}{l}\text { Three-City } \\
\text { Study }\end{array}$ & $\begin{array}{l}\text { AGES- } \\
\text { Reykjavik }\end{array}$ \\
\hline Country & France & Netherlands & USA & Sweden & UK & UK & France & Iceland \\
\hline Sample size & 2,960 & 10,235 & 2,596 & 1,168 & 6,441 & 11,788 & 8,250 & 5,764 \\
\hline $\begin{array}{l}\text { Dementia follow- } \\
\text { up, y }\end{array}$ & 27 & 25 & 25 & 23 & 2 & 2 & 13.5 & 6 \\
\hline Mean age, $y$ & 75.3 & 71.4 & 72.1 & 76.1 & 76.4 & 76.0 & 74.0 & 77.0 \\
\hline Women, \% & 58.0 & 58.0 & 59.2 & 100 & 61.6 & 56.1 & 61.3 & 57.7 \\
\hline $\begin{array}{l}\text { Caucasian } \\
\text { ethnicity, \% }\end{array}$ & a & 98.6 & 100 & $\mathrm{a}$ & 99.1 & 97.2 & 100 & 100 \\
\hline Person-years & 19,314 & 74,517 & 29,906 & 6,368 & 12,850 & 25,319 & 64,561 & 23,970 \\
\hline Incident dementia & 578 & 766 & 685 & 145 & 261 & 390 & 951 & 477 \\
\hline Incident AD & 455 & 521 & 540 & a & a & a & 653 & 150 \\
\hline
\end{tabular}

Abbreviations: AD = Alzheimer disease; AGES-Reykjavik Study = Age, Gene/Environment Susceptibility-Reykjavik Study; CFAS = Cognitive Function and Ageing Studies; PAQUID = Personnes Agées QUID.

${ }^{a}$ Data not collected.

comparison study. This comparison study, with independent sampling across 3 similar sites, was initiated 2 decades later, with baseline interviewing undertaken from 2008 to 2010 (CFAS II; response 56\%). For this analysis, the baseline and 2-year follow-up data are included. The FHS began in 1948 with the recruitment of an original cohort of 5,209 men and women who were 28-62 years of age at entry. ${ }^{12}$ In 1971, a second generation of study participants, including 5,124 children and spouses of children of the original cohort, were enrolled. ${ }^{13}$ The Gothenburg population studies consist of 4 studies among individuals representative of the Swedish population. ${ }^{14,15}$ These include Prospective Population Study of Women, a study that includes 1,462 women aged 38 to 60 who have been followed since 1968; the Gothenburg H70 Birth Cohort Studies, which studies several birth cohorts of 70-year-olds recruited from 1971 and onwards, of which a cohort of 70year-olds enrolled in 2000 were included in this study; and the second H85 study, which started in 2009 with the enrolment of a birth cohort of 85-year-olds. The PAQUID cohort is a population-based study in the southwest of France among 3,777 individuals aged 65 years or older recruited in $1988 .{ }^{16}$ There have been 12 subsequent waves of data collection at $1,3,5,8,10,13,15,17,20,22,25$, and 27 years after the baseline assessment. Due to changes in diagnoses over the first years of follow-up, for trends analysis, only data from the 8-year follow-up were included. ${ }^{17}$ The RS is a prospective population-based cohort study comprising 14,926 participants aged 45 years or older. ${ }^{18}$ Baseline data of 7,983 participants were collected between 1990 and 1993 (response 78\%), with subsequent cohort expansions in 2000 (3,011 individuals, 67\%) and 2006 (3,236 individuals, 65\%). Participants are interviewed at home and reexamined at a dedicated research center once every 4 years. The entire cohort is continuously under surveillance for disease outcomes through linkage of electronic medical records with the study database. $3 \mathrm{C}$ is a longitudinal population-based study of the relation between vascular diseases and dementia in persons aged 65 years and older. ${ }^{19}$ Between 1999 and 2001, a total of 9,294 noninstitutionalized persons were recruited from the electoral rolls of 3 French cities: Bordeaux (southwest), Dijon (northeast), and Montpellier (southeast). Extensive follow-up examinations were performed at home or in a dedicated research center every 2 years after the baseline assessment, comprising standardized questionnaires, clinical examinations, and detailed cognitive assessment. An overview of the study populations is presented in table 1 .

The ARIC study and the CHS, which are also part of the ACC, were not included in these analyses as ARIC did not have sufficient follow-up at the time of these analyses and the CHS had consistent data on long-term follow-up available in only a small subset of the (Pittsburgh) population only.

\section{Assessment of dementia and Alzheimer disease (AD)}

Our primary outcome of interest is a diagnosis of all-cause dementia with a secondary outcome of clinical $\mathrm{AD}$, where available. Dementia diagnostic criteria were consistent across the study period for each study, and are based on either DSMIII-R (CFAS, Gothenburg studies, PAQUID, and RS) or DSM-IV (AGES, FHS, and 3C). The National Institute of Neurologic and Communicative Disorders and StrokeAlzheimer's Disease and Related Disorders Association (NINCDS-ADRDA) criteria $^{20}$ for $\mathrm{AD}$ diagnosis was used in all cohorts except CFAS and the Gothenburg studies, which did not have data on $\mathrm{AD}$ diagnosis. 


\section{Statistical analysis}

Poisson regression was used to calculate 5-year incidence rates (IRs) and 95\% confidence intervals (CIs). All models were adjusted for age at time of entry and sex, and the log of follow-up time was used as an offset variable with IRs presented for the middle age of each 5-year age group (e.g., for 65 to 69.9 age group we used the middle age of 67.5). A single participant was able to contribute to multiple age groups as long as that person was free from dementia at the start of the age-group category. A robust sandwich estimator was used to calculate the $95 \% \mathrm{CI}$ to control for the violation of the independence assumption. ${ }^{21}$ Models for all-cause dementia were stratified by age and sex. Due to limited data and followup among men, the Gothenburg studies included only women for these analyses. For comparison between men and women, results from the sex-specific IRs were analyzed across all cohorts using the meta-package (version 4.8-4) of the statistical software $\mathrm{R}$, version 3.4.2 with heterogeneity across studies being assessed with an $I^{2}$ statistic.

Cohorts with sufficient follow-up data to create at least 2 epochs were included in the trends analysis. Cohort-specific, nonoverlapping epochs were created in order to maximize the person-years available in each cohort, with 2 epochs in 3C, 3 epochs in PAQUID, RS, and the Gothenburg studies, and 4 epochs in FHS. Cox proportional hazard regression models were used to calculate the 5-year cumulative hazards per epoch, and hazard ratios (HRs) for all-cause dementia and $\mathrm{AD}$ for each epoch relative to the first. In CFAS, Bayesian full likelihood imputation models were used to adjust for study design of CFAS I. ${ }^{22}$ All models were adjusted for age at entry of the epoch and sex, with the exception of the sex-stratified models, which were adjusted solely for age. Participants were included in an epoch if they were free of dementia at the beginning of the epoch and censored at the end of 5 years, at their last visit, when lost to follow-up, or at date of death, whichever came first. Similar to the incidence analyses, participants contributed to multiple epochs if they were free of dementia at the beginning of the epoch and we utilized a robust sandwich estimator for the covariance structure to estimate the $95 \%$ confidence limits to account for nonindependence. ${ }^{21}$ To compare temporal trends across studies, we then calculated a HR per 10-year change in calendar time. This is interpreted as a change in 5-year hazard per decade advance in calendar time and was estimated using years from the median date of the referent first epoch to the median start date of each epoch, divided by 10 and treated as a continuous variable in the model. This assumes the time trend is constant across the 25-year study period. Trends were meta-analyzed across all cohorts, with heterogeneity across studies assessed with an $I^{2}$ statistic using the meta-package (version 4.8-4) of the statistical software $R$, version 3.4.2. To rule out any dominant effect of the largest studies on the pooled estimate, we performed sensitivity analyses in which we excluded one by one the studies with the largest weight until a minimum of 3 studies.
To visualize the impact of changing incidence in dementia both globally and within Europe and the United States, we used data from the 2012 and 2015 World Alzheimer Reports to estimate how a decreasing trend in incidence would impact the expected number of new cases per year by 2040. We used the change in total cases/year between 2010 and 2015 and extrapolated that same change for each 5-year interval, taking into account the increasing population size and increasing longevity through to 2040, which resulted in similar projections as given in the 2012 report. We then estimated the effect of a continued decline in incidence on the total number of new dementia cases until 2040, assuming effect estimates for time trends from the present study.

All analyses were done separately by investigators responsible for each cohort. In order to ensure harmonization in analyses, each cohort received a detailed analysis plan, including statistical code in both SPSS (IBM Corp., Armonk, NY) and SAS (SAS Institute, Cary, NC).

\section{Data availability}

Framingham Study data are available through BioLINCC, where qualified researchers can apply for authorization to access (biolincc.nhlbi.nih.gov/studies/framcohort/?q=Framingham).

Data of European cohorts are available upon request, after approval by the relevant institutional review boards, in keeping with informed consent and the national and EU data protection regulations. Requests can be directed to the following contacts: for AGES, the Icelandic Heart Association (AGES_data_request@hjarta.is); for RS, data manager Frank J.A. van Rooij (f.vanrooij@erasmusmc.nl); for CFAS, the national coordinator of the CFAS Collaboration Data Archive, Linda Barnes (leb22@ medschl.cam.ac.uk); for 3C, the principal investigator Dr. Christophe Tzourio (E3C.CoordinatingCenter@gmail.com or christophe.tzourio@u-bordeaux.fr); for PAQUID, the coordinating investigator Dr. Catherine Helmer (catherine.helmer@u-bordeaux.fr); and for the Gothenburg Studies, the principal investigator Dr. Ingmar Skoog (Ingmar.Skoog@ neuro.gu.se).

\section{Results}

Cohort characteristics and demographics of participants in the analyses per cohort are presented in table 1. Data on nearly 50,000 participants with 2-27 years of follow-up are included in this study. All the cohorts comprise more women than men, with a mean relative frequency of $59 \%$. Mean age at baseline of the first epoch was between 71 and 77 for all cohorts (table 1).

A total of 49,202 participants were included in the incidence analyses and followed for a total of 256,805 person-years. A total of 4,253 incident cases of dementia were recorded in the data analyzed for the included 


\begin{tabular}{|c|c|c|c|c|c|c|c|c|}
\hline & PAQUID & Rotterdam Study & Framingham Heart Study & Gothenburg studies & CFAS I & CFAS II & Three-City Study & AGES-Reykjavik \\
\hline Sample size & 4,498 & 10,235 & 1,986 & 1,168 & 6,441 & 11,788 & 12,845 & 5135 \\
\hline Person-years & 18,513 & 74,517 & 20,615 & 6,368 & 12,850 & 25,319 & 53,808 & 22,386 \\
\hline Incident dementia & 491 & 766 & 592 & 145 & 261 & 390 & 634 & 369 \\
\hline \multicolumn{9}{|l|}{ Age groups, y } \\
\hline $65-69$ & $3.2(1.8-5.5)$ & $5.7(4.0-8.1)$ & $1.6(0.6-4.5)$ & NA & $8.6(5.2-14.2)$ & $5.0(3.0-8.7)$ & $2.0(0.1-0.3)$ & $4.5(2.7-6.5)$ \\
\hline $70-74$ & $5.9(3.6-9.3)$ & $19.5(15.7-22.4)$ & $9.7(7.1-13.3)$ & $8.0(5.4-11.8)$ & $11.0(6.8-17.7)$ & $8.2(5.4-12.6)$ & $6.3(0.5-0.8)$ & $7.9(6.4-9.5)$ \\
\hline $75-79$ & $26.5(22.2-31.5)$ & $37.2(31.3-44.3)$ & $17.9(1.4-2.2)$ & $18.6(10.2-33.6)$ & $18.6(11.7-29.4)$ & $16.4(11.4-23.6)$ & $12.8(1.3-1.5)$ & $15.7(13.4-18.1)$ \\
\hline $80-84$ & $43.6(37.6-50.6)$ & $58.3(48.3-70.4)$ & $41.0(3.5-48.4)$ & $43.2(29.6-62.9)$ & $41.2(29.3-57.9)$ & $32.1(23.4-44.1)$ & $23.1(2.0-2.7)$ & $37.3(33.3-41.5)$ \\
\hline $85-89$ & $73.1(62.3-85.9)$ & $97.0(76.9-122.2)$ & $67.9(56.5-81.5)$ & $73.3(27.1-200.9)$ & $56.3(38.9-81.4)$ & $42.2(28.3-62.7)$ & $48.2(4.0-5.8)$ & $66.3(56.3-76.8)$ \\
\hline \multicolumn{9}{|l|}{ Men only } \\
\hline Sample size & 1826 & 4,296 & 782 & NA & 2,279 & 5575 & 4,834 & 2,177 \\
\hline Person-years & 7,491 & 30,849 & 7,685 & NA & 4,533 & 11,961 & 19,626 & 9,177 \\
\hline Incident dementia & 158 & 271 & 188 & NA & 95 & 173 & 214 & 155 \\
\hline \multicolumn{9}{|l|}{ Age groups, y } \\
\hline $65-69$ & $5.1(2.6-9.8)$ & $7.3(4.3-12.5)$ & $3.4(1.5-7.3)$ & NA & $10.9(5.7-20.6)$ & $5.4(2.6-11.3)$ & $2.3(0.1-0.5)$ & $4.1(1.5-7.2)$ \\
\hline $70-74$ & $7.5(4.0-14.0)$ & $19.2(14.0-26.4)$ & $7.8(5.1-11.8)$ & NA & $14.8(8.0-27.5)$ & $10.1(5.8-17.6)$ & $7.0(0.5-1.0)$ & $7.0(4.9-9.3)$ \\
\hline $75-79$ & $25.6(19.3-33.9)$ & $43.5(33.1-57.2)$ & $22.6(17.6-29.0)$ & NA & $22.0(8.1-59.2)$ & $13.6(7.0-26.6)$ & $11.8(0.9-1.5)$ & $16.8(13.3-20.6)$ \\
\hline $80-84$ & $31.2(23.3-41.8)$ & $57.1(41.8-78.0)$ & $25.0(18.7-33.2)$ & NA & $47.3(27.6-81.2)$ & $22.3(12.4-38.9)$ & $19.3(1.5-2.6)$ & $39.8(33.1-46.4)$ \\
\hline $85-89$ & $58.7(42.7-80.5)$ & 118.9 (76.5-184.8) & $73.6(57.0-95.1)$ & NA & $70.4(35.8-138.3)$ & $37.7(22.4-63.4)$ & $49.0(3.5-6.9)$ & $62.1(45.1-76.2)$ \\
\hline \multicolumn{9}{|l|}{ Women only } \\
\hline Sample size & 2,672 & 5,939 & 1,204 & 1,168 & 4,163 & 6,914 & 8,011 & 2,958 \\
\hline Person-years & 11,022 & 43,668 & 12,930 & 6,368 & 8,317 & 14,787 & 33,183 & 13,209 \\
\hline Incident dementia & 333 & 495 & 404 & 145 & 166 & 300 & 420 & 214 \\
\hline \multicolumn{9}{|l|}{ Age groups, y } \\
\hline $65-69$ & $1.6(0.6-4.5)$ & $4.6(2.9-7.4)$ & $1.7(0.6-4.6)$ & NA & $6.4(3.0-13.7)$ & $4.7(2.1-10.2)$ & $1.8(0.1-0.4)$ & $4.7(2.4-7.3)$ \\
\hline & & & & & & & & Continued \\
\hline
\end{tabular}


cohorts (table 1). Across all cohorts, IRs by age group were consistent (table 2). As expected, the incidence of dementia increased with age, from 1.6 to 8.6 per 1,000 person-years in the youngest age group (65-69 years), to between 42.2 and 97.0 per 1,000 person-years in the oldest age group (85-89 years). In general, the CFAS II cohort and the FHS had the lowest IRs and RS observed the highest (figure 1). This pattern was similar for the sexspecific results. When results were combined across cohorts, we saw little difference in IRs by age group, or between men and women (figure 2).

We directly compared and analyzed the 5-year HRs per 10year increment in calendar time between cohorts. This showed a consistent decrease in the 5-year cumulative hazard of all-cause dementia in all cohorts (figure 3A; table 3). Across studies, we saw a 13\% (95\% CI 7\%-19\%) decrease in all-cause dementia per decade since 1998. Patterns were similar for clinical AD (decrease per decade: $16 \%$ [8\%-24\%]; figure 3B). The decrease in 5-year cumulative hazard for all-cause dementia was larger in men than women, with a $24 \%$ decrease $(14 \%-33 \%)$ in men vs an $8 \%$ decrease $(0 \%-15 \%)$ in women, again with little heterogeneity across studies ( $I^{2}=0 \%$ and $5 \%$, respectively) (figure $3, \mathrm{C}$ and $\mathrm{D}$ ). Results were broadly unaltered by stepwise analysis excluding the 3 studies with the largest weight, with HRs (95\% $\mathrm{CI})$ of 0.84 (0.78-0.92), 0.87 (0.77-0.97), and 0.82 (0.71-0.95), after exclusion of, respectively, CFAS; CFAS and RS; and CFAS, RS, and FHS.

\section{Discussion}

In this analysis of data from 7 large cohort studies representing populations from 6 different countries, we show that the age-stratified IRs of dementia are consistent across cohorts and notably similar between men and women. When examining changes in the IR over the past 25 years, we observe a decline of $13 \%$ per decade, again consistent across studies, but somewhat stronger for men compared to women. If we assume continuation of this trend in Europe and North America into the coming decades-although this was not the main objective of our study-it could imply that 15 million fewer people will develop dementia by 2040 in high-income countries, compared to widely quoted projections of the global burden of disease. ${ }^{23}$ If the same continuous incidence reduction could be achieved worldwide, this could lead to a reduction in the expected incidence of dementia of up to 60 million new cases of dementia by 2040 (figure 4).

Several of the cohorts within the ACC have previously published data on time trends in the incidence of dementia. ${ }^{4,5,7,8}$ The incidence trends described here are an important step towards consensus, with substantially greater precision arising from using consistent analytical techniques across cohorts. In addition, our analyses suggest that these time trends in 
Figure 1 Incidence rates of dementia, stratified by cohort and age group

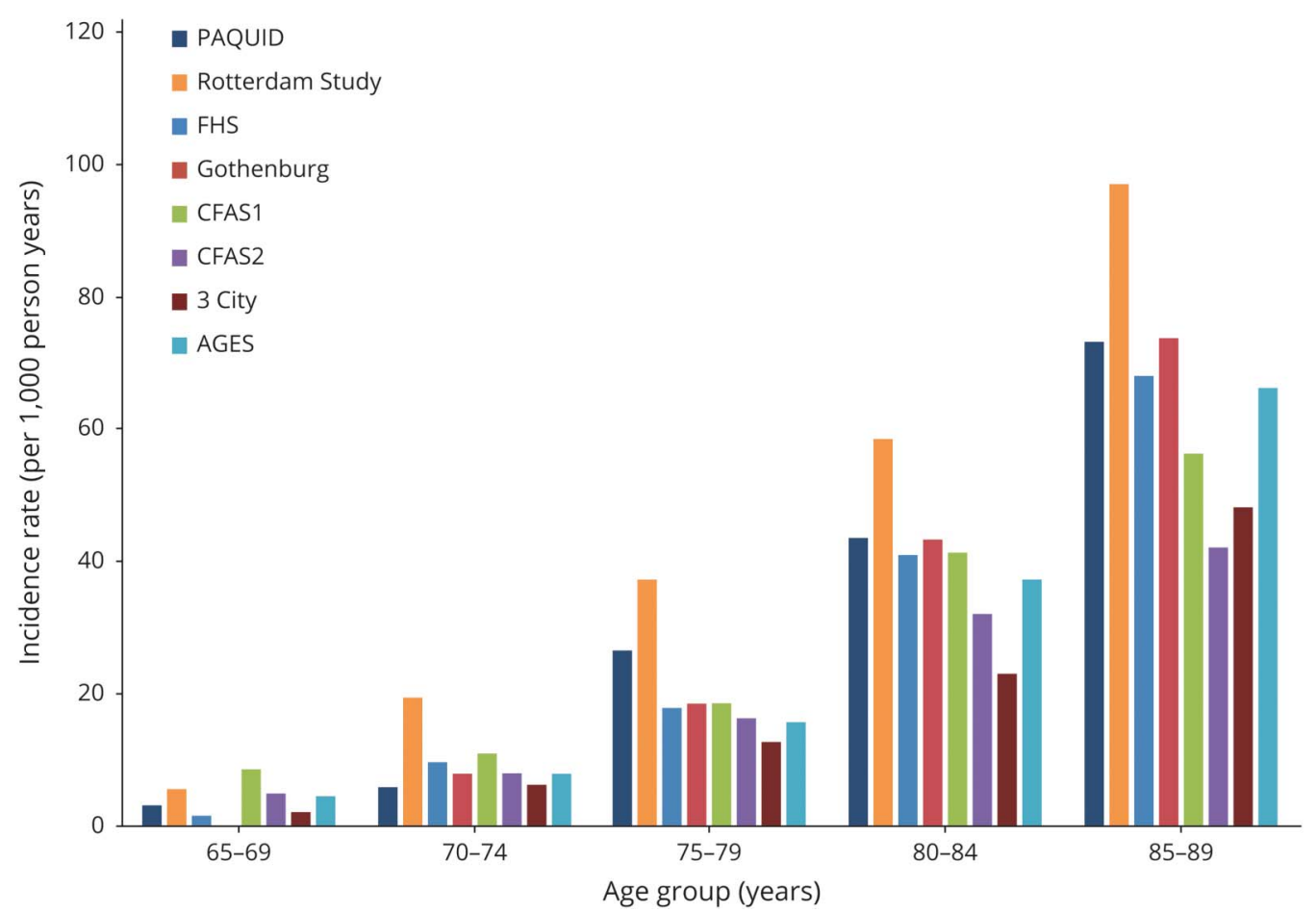

AGES-Reykjavik Study = Age, Gene/Environment Susceptibility-Reykjavik Study; CFAS = Cognitive Function and Ageing Studies; FHS = Framingham Heart Study; PAQUID = Personnes Agées QUID.

Figure 2 Incidence rates of dementia by age group, comparing men vs women

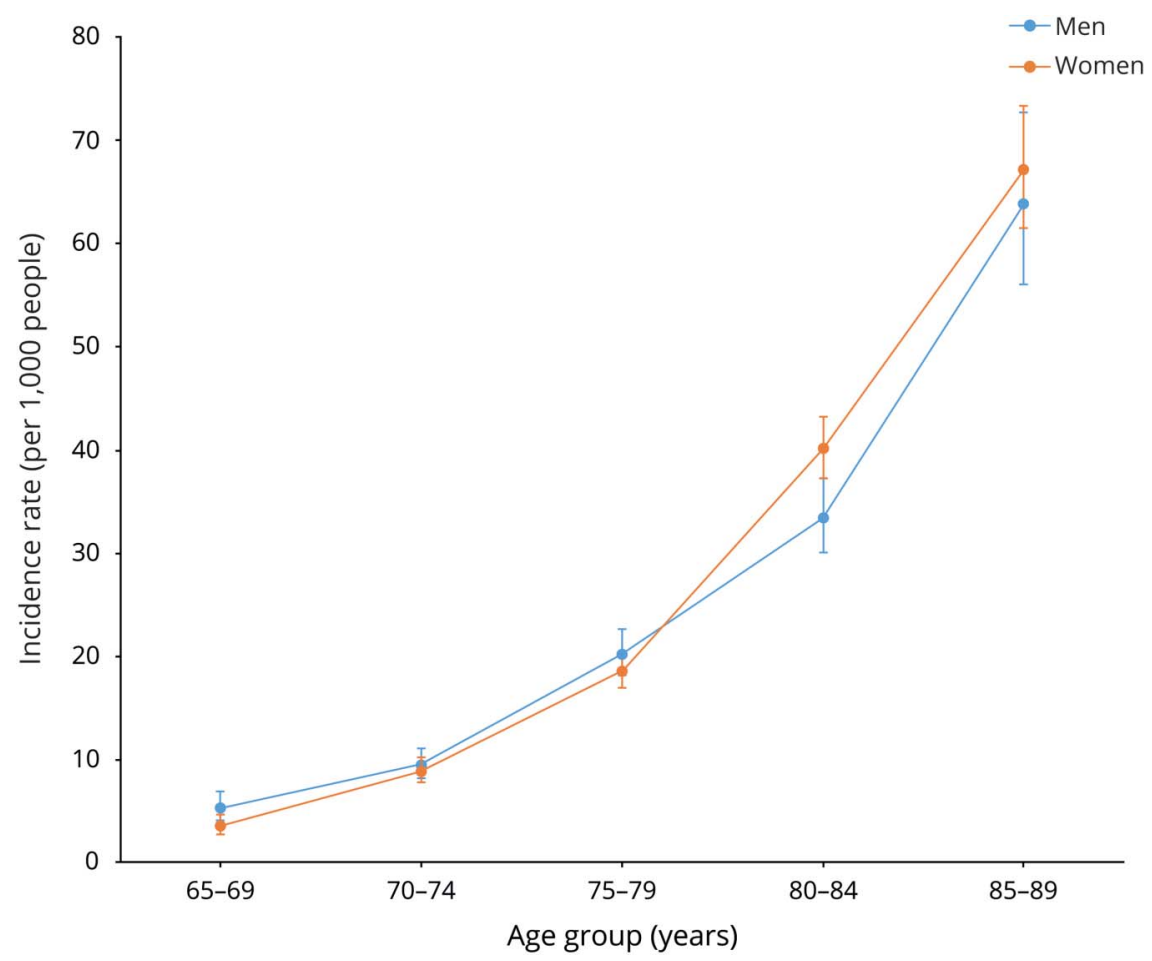




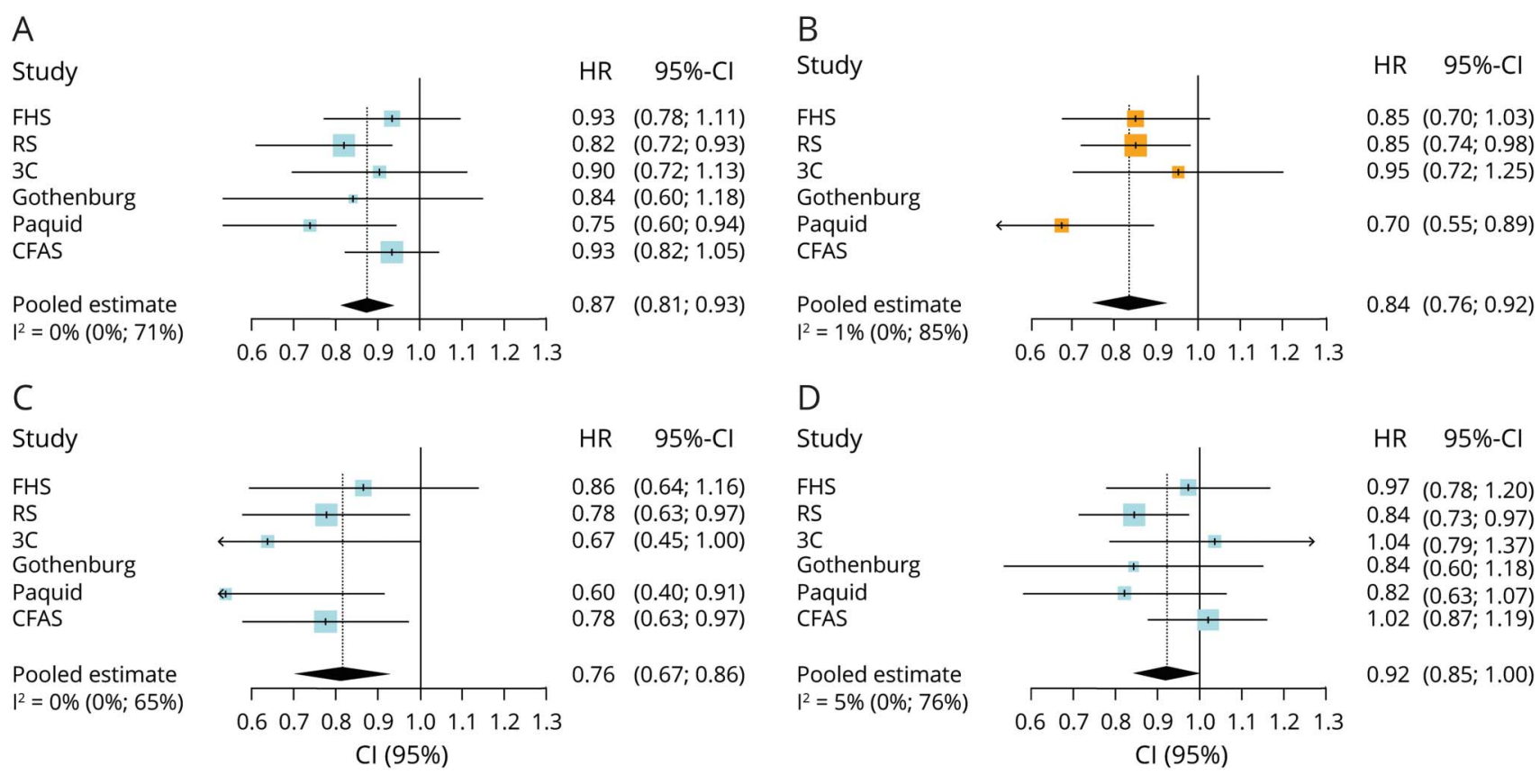

The forest plots represent the incidence trend for (A) all-cause dementia, (B) Alzheimer disease, (C) all-cause dementia in men, and (D) all-cause dementia in women, expressed as a hazard ratio (HR) per 10-year advance in calendar time. This HR was calculated to compare temporal trends across studies, and can be interpreted as a change in the 5-year hazard per decade advance in calendar time. $3 \mathrm{C}=$ Three-City Study; CFAS = Cognitive Function and Ageing Studies; CI = confidence interval; FHS = Framingham Heart Study; RS = Rotterdam Study.

dementia incidence have occurred in both men and women. However, the effects of this decline in age-specific incidence will also depend on concurrent changes in life expectancy. ${ }^{24}$ Reductions in years spent with cognitive disability in the United Kingdom from 1991 to 2011, 5 and reductions in years lived with dementia in the United States over the last 30 years, ${ }^{7}$ raise hope that preventive efforts involving lifestyle and health care interventions against dementia can offset at least part of the growing burden of dementia from global gains in life expectancy.
The study has strengths and limitations. This analysis has greater precision derived from combining several large, longterm population-based cohorts that have strived to limit person attrition from the studies over many years. We have described methodologic considerations for studying trends in the incidence of dementia previously. ${ }^{10}$ It is important to note that despite inevitable differences in population demographics, genetic and lifestyle make-up, and ascertainment methods for dementia, incidence trends displayed relatively little heterogeneity across studies. Further, concurrent

Table 3 Change in incidence per decade by study and sex

\begin{tabular}{|c|c|c|c|c|c|c|c|}
\hline & PAQUID & $\begin{array}{l}\text { Rotterdam } \\
\text { study }\end{array}$ & $\begin{array}{l}\text { Framingham heart } \\
\text { study }\end{array}$ & $\begin{array}{l}\text { Gothenburg } \\
\text { studies }^{\text {a }}\end{array}$ & CFAS I/II & $\begin{array}{l}\text { Three-City } \\
\text { Study }\end{array}$ & $\begin{array}{l}\text { Meta-analysis } \\
\text { (random-effects) }\end{array}$ \\
\hline $\begin{array}{l}\text { All-cause } \\
\text { dementia }\end{array}$ & $\begin{array}{l}0.75 \\
(0.60-0.94)\end{array}$ & $\begin{array}{l}0.82 \\
(0.73-0.93)\end{array}$ & $0.93(0.79-1.11)$ & $0.84(0.60-1.18)$ & $\begin{array}{l}0.93 \\
(0.82-1.05)\end{array}$ & $\begin{array}{l}0.90 \\
(0.71-1.13)\end{array}$ & $0.87(0.81-0.93)$ \\
\hline $\begin{array}{l}\text { Alzheimer } \\
\text { disease }\end{array}$ & $\begin{array}{l}0.70 \\
(0.55-0.89)\end{array}$ & $\begin{array}{l}0.85 \\
(0.74-0.98)\end{array}$ & $0.85(0.71-1.03)$ & & & $\begin{array}{l}0.95 \\
(0.72-1.25)\end{array}$ & $0.84(0.76-0.92)$ \\
\hline \multicolumn{8}{|l|}{ Sex } \\
\hline Men & $\begin{array}{l}0.60 \\
(0.39-0.91)\end{array}$ & $\begin{array}{l}0.78 \\
(0.63-0.97)\end{array}$ & $0.86(0.64-1.16)$ & NA & $\begin{array}{l}0.78 \\
(0.63-0.97)\end{array}$ & $\begin{array}{l}0.67 \\
(0.45-1.00)\end{array}$ & $0.76(0.67-0.86)$ \\
\hline Women & $\begin{array}{l}0.82 \\
(0.63-1.07)\end{array}$ & $\begin{array}{l}0.84 \\
(0.72-0.97)\end{array}$ & $0.97(0.78-1.20)$ & $0.84(0.60-1.18)$ & $\begin{array}{l}1.02 \\
(0.86-1.19)\end{array}$ & $\begin{array}{l}1.04 \\
(0.78-1.37)\end{array}$ & $0.92(0.85-1.00)$ \\
\hline
\end{tabular}

Abbreviations: CFAS = Cognitive Function and Ageing Studies; PAQUID = Personnes Agées QUID.

Values are hazard ratio (95\% confidence interval).

a Includes only women. 


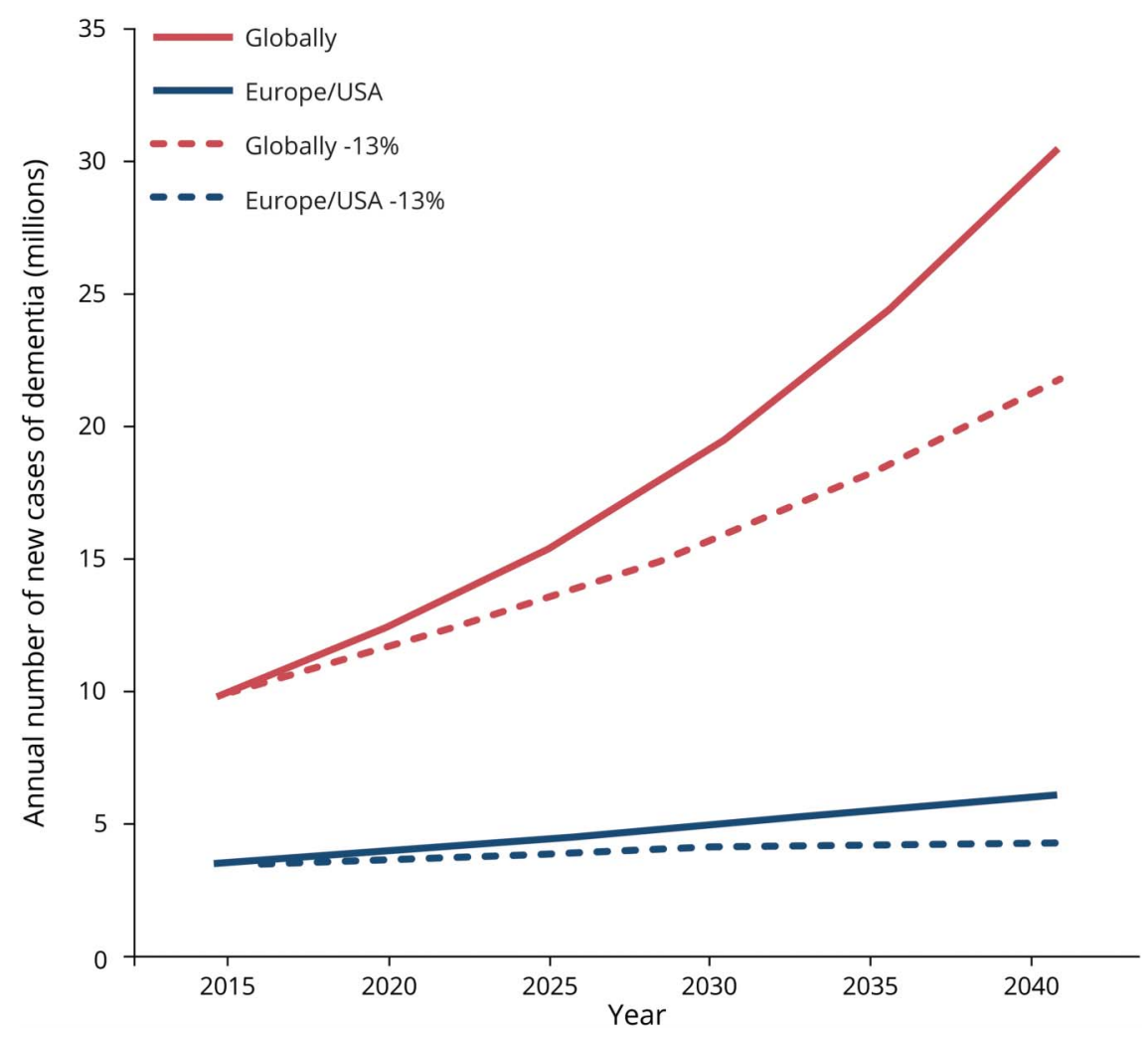

Projected yearly incidence of dementia on the basis of current rates (solid lines) and projected incidence of dementia assuming continuation of a decreasing trend (dashed lines). Current rates are based on estimates from the 2012 World Alzheimer Report, which at the time estimated that 682 million new cases would occur over the 2010 to 2050 period. increases in life expectancy and increased awareness of dementia in the population may have led to underestimation of a downward trend arising from increased diagnosis efficiency.

As a first limitation, despite extensive efforts to limit attrition, differential dropout may have occurred when linkage to health records was not available. However, attrition that is constant over time is unlikely to affect secular trends. Second, while the definition of dementia as a syndrome has remained relatively constant, the definition and understanding of what should be called $\mathrm{AD}$ have shifted substantially over the past decades. In the absence of pathologically confirmed diagnoses in most cohort studies, it remains uncertain what pathologic changes may underlie the observed trends. Third, calculating the effect of the observed trends on future dementia incidence relies on various assumptions that were beyond the scope of the current study to address entirely, and studies applying multistate modeling remain required for accurate projections in light of changing risk factor burden and mortality. Fourth, the application of consistent entry criteria helped guarantee valid assessment of incidence trends, but may have led to selection of a somewhat healthier population and consequently underestimation of absolute IRs. Finally, the choice to limit our analyses to population-based cohorts in order to get the most accurate measure of population incidence has led to a study population containing only those of European ancestry living in either the United States or Europe, with a generalizability of our findings to no more than $16 \%$ of the world's total population. These analyses should therefore be expanded to include (future) population studies with more diverse populations both within the United States and around the globe.

A main challenge in finding a cause of declining temporal trends in dementia is that there have been many concurrent changes over time in possible key risk factors, including lifestyle education and health interventions such as blood pressure control and antithrombotic medication. While none of these has been specifically intended to halt cognitive decline, decades of cardiovascular risk management have likely had substantial effects on brain health, supported by reduction of small-vessel disease on brain imaging in more recent years. ${ }^{8}$ The challenge remains to identify the critical causal factors among a variety of interventions influencing blood pressure, cholesterol, and inflammation that may have contributed to the decrease. Improved access and provision of education is another major change over the past century that could explain decreasing dementia IRs over time. ${ }^{25}$

Contrasting reports on the incidence of dementia have emerged recently from Japan, ${ }^{26}$ China, $^{27}$ and Nigeria, ${ }^{28}$ showing stable or even increasing IRs. Similarly, in multiethnic populations in the United States, declines have been seen in some, ${ }^{29}$ but not all studies. ${ }^{30}$ Against the backdrop of the large expected increases in dementia burden, particularly 
in Asia and Africa, ${ }^{23}$ these observations temper the optimism for low to middle income countries, and render it all the more necessary to unravel the causes underlying the trends seen in this present study. Comparison with other geographic regions may well aid in pinpointing similar or discordant trends. Overall increased ethnic and geographic diversity within the ACC and the wider research community is therefore an important ongoing goal.

The development we see now in the epidemiology of dementia is somewhat reminiscent of the first report of a decline in mortality from coronary heart disease in $1964 .{ }^{31}$ If history has taught us anything in that respect, it is the need for prolonged, consistent surveillance of disease and associated factors to enable the future modeling of trends and the identification of causes. ${ }^{9,31}$ Similar to heart disease, ${ }^{31}$ we should caution that the rise on a global scale of obesity, ${ }^{32}$ diabetes, ${ }^{33}$ and hyperten$\operatorname{sion}^{34}$ may reverse trends in dementia over the coming decades. As such, continued surveillance for dementia in the population-based studies within the ACC provides the framework for further investigation of potential causes of the declining time trend in dementia incidence.

The incidence of dementia in Europe and North America is very similar among men and women and has declined by $13 \%$ per decade over the past 3 decades. Identification of the underlying causes is vital to sustain and possibly enhance these trends in the face of changing risk factor profiles. It is essential to achieve equal reductions in areas of the world where projected increases in dementia burden are steep, and improvements in incidence thus far absent.

\section{Study funding}

The present study was supported by an unrestricted grant from Janssen Prevention Center, Leiden, the Netherlands. Funding for individual cohorts: Age, Gene/Environment Susceptibility (AGES) is supported by National Institute of Aging contracts (N01-AG-12100 and HHSN271201200022C) with contributions from the National Eye Institute, National Institute on Deafness and Other Communication Disorders, the National Heart, Lung and Blood Institute, the National Institute of Aging Intramural Research Program, Hjartavernd (the Icelandic Heart Association), and the Althingi (the Icelandic Parliament). Cognitive Function and Ageing Studies (CFAS): Medical Research Council (MRC) CFAS I was funded by the MRC (Research Grant: G9901400) and the National Health Service (NHS). CFAS II has been supported by the UK Medical Research Council (Research Grant: G06010220) and received additional support from the National Institute for Health Research (NIHR), comprehensive clinical research networks in West Anglia, Nottingham City, and Nottinghamshire County NHS Primary Care trusts, and the Dementias and Neurodegenerative Disease Research Network (DeNDRoN) in Newcastle. Framingham Heart Study (FHS) was supported by the National Heart, Lung, and Blood Institute's Framingham Heart Study (contracts N01HC-25195 and HHSN268201500001I). This study was also supported by grants from the National Institute on Aging (AG054076, U01-AG049505, and AG008122, R01AG049607, AG033193, AG033040, AG052409, AG59421) and the National Institute of Neurologic Disorders and Stroke (R01NS017950, NS100605). The Gothenburg study was supported by grants from The Swedish Research Council 2012-5041, 2015-02830, 2013-8717, Swedish Research Council for Health, Working Life and Welfare (no. 2001-2646, 2003-0234, 2004 0150, 2006-0020, 2008-1229, 2012-1138, 2004-0145, 20060596, 2008-1111, 2010-0870, 2013-1202, 2001-2849, 20050762, 2008-1210, 2013-2300, 2013-2496), Konung Gustaf V:s och Drottning Victorias Frimurarestiftelse, Hjärnfonden, Swedish State Support for Clinical Research (ALF Västra Götalandsregionen), the Swedish state under the agreement between the Swedish Government and the county councils, the ALF-agreement (ALFGBG-813921, ALFGBG-65930, ALFGBG-716681), The Alzheimer's Association Zenith Award (ZEN-01-3151), The Alzheimer's Association Stephanie B. Overstreet Scholars (IIRG-00-2,159), Alzheimer's Association (IIRG-03-6,168), The Alzheimer's Association (IIRG-09131338), Eivind och Elsa K:son Sylvans stiftelse, Stiftelsen Söderström-Königska Sjukhemmet, Stiftelsen för Gamla Tjänarinnor, Handlanden Hjalmar Svenssons Forskningsfond, Stiftelsen Professor Bror Gadelius' Minnesfond, and Swedish Alzheimer foundation. The PAQUID cohort was supported by IPSEN France, NOVARTIS Pharma France, and the CNSA (Caisse Nationale de Solidarité et d'Autonomie). The research presented in this manuscript is original. The contents of this article are solely the responsibility of the authors. IPSEN, NOVARTIS, and the CNSA did not fund this specific study. The funders had no role in the collection, management, analysis, or interpretation of the data and had no role in the preparation, review, or approval of the manuscript. The Rotterdam Study is supported by the Erasmus Medical Centre and Erasmus University Rotterdam, The Netherlands Organization for Scientific Research (NWO), The Netherlands Organization for Health Research and Development (ZonMW), the Research Institute for Diseases in the Elderly (RIDE), The Netherlands Genomics Initiative, the Ministry of Education, Culture and Science, the Ministry of Health, Welfare and Sports, the European Commission (DG XII), and the Municipality of Rotterdam. This research was further supported by funding from the European Union Seventh Framework Program (FP7/2007e2013) under grant agreement no. 601055, VPH-Dare@IT (FP7-ICT-2011-9e601055) and funding from the European Union's Horizon 2020 research and innovation program under grant agreement no. 667375 (Co-STREAM) and under grant agreement no. 678543 (European Research Council [ERC] funded project: ORACLE). None of the funding organizations or sponsors were involved in study design, in collection, analysis, and interpretation of data, in writing of the report, or in the decision to submit the article for publication. The Three-City Study is conducted under a partnership agreement among INSERM, Bordeaux School of Public Health (ISPED) of the University of Bordeaux, and SanofiAventis. The "Fondation pour la Recherche Médicale" funded the preparation and initiation of the study. The Three-City 
Study is also supported by the "Caisse Nationale Maladie des Travailleurs Salariés," "Direction Générale de la Santé," "Mutuelle Générale de l'Education Nationale," "Institut de la Longévité," "Conseils Régionaux of Aquitaine and Bourgogne," "Fondation de France," and Ministry of Research-INSERM Programme "Cohortes et collections de données biologiques," French National Research Agency COGINUT ANR-06PNRA-005 and COGICARE ANR Longvie (LVIE-003-01), the "Fondation Plan Alzheimer" (FCS 2009-2012), and the "Caisse Nationale pour la Solidarité et l'Autonomie." Infrastructure for the CHARGE Consortium is supported in part by National Heart, Lung and Blood Institute (HL105756) and for the neurology working group by National Institutes of Aging (AG033193, AG049505, AG059421, and AG058589).

\section{Disclosure}

F. Wolters, L. Chibnik, and R. Waziry report no disclosures relevant to the manuscript. $\mathrm{R}$. Anderson is an independent scientific nonexecutive director of GlaxoSmithKline (GSK). GSK has no active research programs of R\&D on Alzheimer or dementia therapies, and played no part in funding this research. Dr. Anderson holds shares in GSK and receives research funding support from GSK for work on pneumococcal vaccines and the development of antibiotic drug resistance. Dr. Anderson receives research funding (an unencumbered educational research grant) from Janssen (part of Johnson \& Johnson) for the development of clinical trial simulators and mathematical models of disease progression. Janssen and Johnson \& Johnson played no part in the writing of this manuscript or in the development of its content. C. Berr, A. Beiser, J. Bis, D. Blacker, D. Bos, and C. Brayne report no disclosures relevant to the manuscript. J. Dartigues reports a grant from Roche outside the submitted work. S. Darweesh and K. Davis-Plourde report no disclosures relevant to the manuscript. F. de Wolf is employed by Janssen Pharmaceuticals of Johnson \& Johnson. S. Debette, C. Dufouil, M. Fornage, J. Goudsmit, L. Grasset, V. Gudnason, and C. Hadjichrysanthou report no disclosures relevant to the manuscript. C. Helmer reports grants and personal fees from Roche outside the submitted work. M.A. Ikram, M.K. Ikram, E. Joas, S. Kern, L. Kuller, L. Launer, O. Lopez, F. Matthews, K. McRae-McKee, O. Meirelles, T. Mosley Jr., and M. Pase report no disclosures relevant to the manuscript. B. Psaty reports service on the Steering Committee of the Yale Open Data Access Project funded by Johnson \& Johnson. C. Satizabal and S. Seshadri report no disclosures relevant to the manuscript. I. Skoog reports grants from Swedish Research Council, grants from Swedish Council for Working Life and Social Research, grants from Swedish State ALF-agreement (ALF 716681) during the conduct of the study, and personal fees from Takeda, outside the submitted work. B. Stephan, H. Wetterberg, M. Wong, A. Zettergren, and A. Hofman report no disclosures relevant to the manuscript. Go to Neurology.org/N for full disclosures.

\section{Publication history}

Received by Neurology July 11, 2019. Accepted in final form January 31, 2020.

\section{Appendix Authors}

\begin{tabular}{lll}
\hline Name & Location & Contribution \\
\hline $\begin{array}{l}\text { Frank J. Wolters, } \\
\text { MD, PhD }\end{array}$ & $\begin{array}{l}\text { Harvard T.H. Chan } \\
\text { School of Public Health, } \\
\text { Boston, MA; Erasmus } \\
\text { MC, Rotterdam, the } \\
\text { Netherlands }\end{array}$ & $\begin{array}{l}\text { Acquired and analyzed } \\
\text { the data, drafted the } \\
\text { manuscript }\end{array}$ \\
& Harvard T.H. Chan & \\
\hline $\begin{array}{l}\text { Lori B. Chibnik, } \\
\text { PhD, MPH }\end{array}$ & $\begin{array}{l}\text { School of Public Health; } \\
\text { Massachusetts General and analyzed } \\
\text { the data, drafted the }\end{array}$ & $\begin{array}{l}\text { manuscript } \\
\text { Hospital, Boston }\end{array}$ \\
\hline
\end{tabular}

\begin{tabular}{|c|c|c|}
\hline $\begin{array}{l}\text { Reem Waziry, MD, } \\
\text { PhD }\end{array}$ & $\begin{array}{l}\text { Harvard T.H. Chan } \\
\text { School of Public Health, } \\
\text { Boston, MA }\end{array}$ & $\begin{array}{l}\text { Interpreted the data, } \\
\text { revised the } \\
\text { manuscript for } \\
\text { intellectual content }\end{array}$ \\
\hline $\begin{array}{l}\text { Roy Anderson, FRS, } \\
\text { FMedSci }\end{array}$ & $\begin{array}{l}\text { School of Public Health, } \\
\text { Imperial College } \\
\text { London, UK }\end{array}$ & $\begin{array}{l}\text { Interpreted the data, } \\
\text { revised the } \\
\text { manuscript for } \\
\text { intellectual content }\end{array}$ \\
\hline $\begin{array}{l}\text { Claudine Berr, MD, } \\
\text { PhD }\end{array}$ & $\begin{array}{l}\text { Univ Montpellier, } \\
\text { Neuropsychiatry, } \\
\text { Epidemiology and } \\
\text { Clinical Research, } \\
\text { Montpellier, France }\end{array}$ & $\begin{array}{l}\text { Interpreted the data, } \\
\text { revised the manuscript } \\
\text { for intellectual content }\end{array}$ \\
\hline Alexa Beiser, PhD & $\begin{array}{l}\text { Boston University } \\
\text { School of Medicine; The } \\
\text { Framingham Heart } \\
\text { Study; Boston } \\
\text { University School of } \\
\text { Public Health, MA }\end{array}$ & $\begin{array}{l}\text { Analyzed and } \\
\text { interpreted the data, } \\
\text { revised the manuscript } \\
\text { for intellectual content }\end{array}$ \\
\hline
\end{tabular}

\begin{tabular}{lll}
\hline Joshua C. Bis, PhD & $\begin{array}{l}\text { Cardiovascular Health } \\
\text { Research Unit, } \\
\text { University of } \\
\text { Washington, Seattle }\end{array}$ & $\begin{array}{l}\text { Analyzed and } \\
\text { interpreted the data, } \\
\text { revised the manuscript } \\
\text { for intellectual content }\end{array}$ \\
\hline $\begin{array}{l}\text { Deborah Blacker, } \\
\text { MD, ScD }\end{array}$ & $\begin{array}{l}\text { Harvard T.H. Chan } \\
\text { School of Public Health; } \\
\text { Massachusetts General } \\
\text { Hospital, Boston }\end{array}$ & $\begin{array}{l}\text { Interpreted the data, } \\
\text { revised the manuscript } \\
\text { for intellectual content }\end{array}$ \\
\hline $\begin{array}{l}\text { Daniel Bos, MD, } \\
\text { PhD }\end{array}$ & $\begin{array}{l}\text { Harvard T.H. Chan } \\
\text { School of Public Health, } \\
\text { Boston, MA; Erasmus } \\
\text { MC, Rotterdam, the }\end{array}$ & $\begin{array}{l}\text { Interpreted the data, } \\
\text { revised the manuscript } \\
\text { for intellectual content }\end{array}$ \\
& Netherlands & \\
\hline
\end{tabular}

\begin{tabular}{|c|c|c|}
\hline Carol Brayne, MD & $\begin{array}{l}\text { University of } \\
\text { Cambridge, Cambridge, } \\
\text { UK }\end{array}$ & $\begin{array}{l}\text { Interpreted the data, } \\
\text { revised the } \\
\text { manuscript for } \\
\text { intellectual content }\end{array}$ \\
\hline $\begin{array}{l}\text { Jean-François } \\
\text { Dartigues, MD, PhD }\end{array}$ & $\begin{array}{l}\text { INSERM, Bordeaux } \\
\text { Population Health } \\
\text { Research Center, } \\
\text { France }\end{array}$ & $\begin{array}{l}\text { Interpreted the data, } \\
\text { revised the manuscript } \\
\text { for intellectual content }\end{array}$ \\
\hline $\begin{array}{l}\text { Sirwan K.L. } \\
\text { Darweesh, MD, } \\
\text { PhD }\end{array}$ & $\begin{array}{l}\text { Erasmus MC, } \\
\text { Rotterdam, the } \\
\text { Netherlands }\end{array}$ & $\begin{array}{l}\text { Interpreted the data, } \\
\text { revised the manuscript } \\
\text { for intellectual content }\end{array}$ \\
\hline $\begin{array}{l}\text { Kendra L. Davis- } \\
\text { Plourde, MA }\end{array}$ & $\begin{array}{l}\text { Boston University } \\
\text { School of Public Health, } \\
\text { Boston, MA USA }\end{array}$ & $\begin{array}{l}\text { Analyzed and } \\
\text { interpreted the data, } \\
\text { revised the manuscript } \\
\text { for intellectual content }\end{array}$ \\
\hline $\begin{array}{l}\text { Frank de Wolf, MD, } \\
\text { PhD }\end{array}$ & $\begin{array}{l}\text { Department of } \\
\text { Infectious Disease } \\
\text { Epidemiology, School } \\
\text { of Public Health, } \\
\text { Imperial College } \\
\text { London, UK }\end{array}$ & $\begin{array}{l}\text { Interpreted the data, } \\
\text { revised the manuscript } \\
\text { for intellectual content }\end{array}$ \\
\hline
\end{tabular}

Continued 
Appendix (continued)

\begin{tabular}{|c|c|c|}
\hline Name & Location & Contribution \\
\hline $\begin{array}{l}\text { Stephanie Debette, } \\
\text { PhD }\end{array}$ & $\begin{array}{l}\text { University of Bordeaux, } \\
\text { INSERM, Bordeaux } \\
\text { Population Health } \\
\text { Research Center; } \\
\text { Bordeaux University } \\
\text { Hospital, France }\end{array}$ & $\begin{array}{l}\text { Interpreted the data, } \\
\text { revised the manuscript } \\
\text { for intellectual content }\end{array}$ \\
\hline $\begin{array}{l}\text { Carole Dufouil, } \\
\text { PhD }\end{array}$ & $\begin{array}{l}\text { University of Bordeaux, } \\
\text { INSERM, Bordeaux } \\
\text { Population Health } \\
\text { Research Center, } \\
\text { France }\end{array}$ & $\begin{array}{l}\text { Interpreted the data, } \\
\text { revised the manuscript } \\
\text { for intellectual content }\end{array}$ \\
\hline $\begin{array}{l}\text { Myriam Fornage, } \\
\text { PhD }\end{array}$ & $\begin{array}{l}\text { University of Texas } \\
\text { Health Science } \\
\text { Center at Houston, } \\
\text { McGovern Medical } \\
\text { School }\end{array}$ & $\begin{array}{l}\text { Interpreted the data, } \\
\text { revised the manuscript } \\
\text { for intellectual content }\end{array}$ \\
\hline $\begin{array}{l}\text { Jaap Goudsmit, } \\
\text { MD, PhD }\end{array}$ & $\begin{array}{l}\text { Harvard T.H. Chan } \\
\text { School of Public Health, } \\
\text { Boston, MA }\end{array}$ & $\begin{array}{l}\text { Interpreted the data, } \\
\text { revised the } \\
\text { manuscript for } \\
\text { intellectual content }\end{array}$ \\
\hline Leslie Grasset, PhD & $\begin{array}{l}\text { University of Bordeaux, } \\
\text { INSERM, Bordeaux } \\
\text { Population Health } \\
\text { Research Center, } \\
\text { France }\end{array}$ & $\begin{array}{l}\text { Analyzed and } \\
\text { interpreted the data, } \\
\text { revised the manuscript } \\
\text { for intellectual content }\end{array}$ \\
\hline $\begin{array}{l}\text { Vilmundur } \\
\text { Gudnason, MD, } \\
\text { PhD }\end{array}$ & $\begin{array}{l}\text { Icelandic Heart } \\
\text { Association, } \\
\text { Kopavogur; Faculty of } \\
\text { Medicine, University of } \\
\text { Iceland, Reykjavik }\end{array}$ & $\begin{array}{l}\text { Interpreted the data, } \\
\text { revised the manuscript } \\
\text { for intellectual content }\end{array}$ \\
\hline $\begin{array}{l}\text { Christoforos } \\
\text { Hadjichrysanthou, } \\
\text { PhD }\end{array}$ & $\begin{array}{l}\text { Department of } \\
\text { Infectious Disease } \\
\text { Epidemiology, School } \\
\text { of Public Health, } \\
\text { Imperial College } \\
\text { London, UK }\end{array}$ & $\begin{array}{l}\text { Interpreted the data, } \\
\text { revised the manuscript } \\
\text { for intellectual content }\end{array}$ \\
\hline $\begin{array}{l}\text { Catherine Helmer, } \\
\text { MD, PhD }\end{array}$ & $\begin{array}{l}\text { University of Bordeaux, } \\
\text { INSERM, Bordeaux } \\
\text { Population Health } \\
\text { Research Center, } \\
\text { France }\end{array}$ & $\begin{array}{l}\text { Interpreted the data, } \\
\text { revised the manuscript } \\
\text { for intellectual content }\end{array}$ \\
\hline $\begin{array}{l}\text { M. Arfan Ikram, } \\
\text { MD, PhD }\end{array}$ & $\begin{array}{l}\text { Department of } \\
\text { Epidemiology, Erasmus } \\
\text { MC, Rotterdam, the } \\
\text { Netherlands }\end{array}$ & $\begin{array}{l}\text { Interpreted the data, } \\
\text { revised the manuscript } \\
\text { for intellectual content }\end{array}$ \\
\hline $\begin{array}{l}\text { M. Kamran Ikram, } \\
\text { MD, PhD }\end{array}$ & $\begin{array}{l}\text { Departments of } \\
\text { Epidemiology \& } \\
\text { Neurology, Erasmus } \\
\text { MC, Rotterdam, the } \\
\text { Netherlands }\end{array}$ & $\begin{array}{l}\text { Interpreted the data, } \\
\text { revised the manuscript } \\
\text { for intellectual content }\end{array}$ \\
\hline Erik Joas, PhD & $\begin{array}{l}\text { Institute of } \\
\text { Neuroscience and } \\
\text { Physiology, } \\
\text { Sahlgrenska } \\
\text { Academy, University } \\
\text { of Gothenburg, } \\
\text { Sweden }\end{array}$ & $\begin{array}{l}\text { Analyzed and } \\
\text { interpreted the data, } \\
\text { revised the manuscript } \\
\text { for intellectual content }\end{array}$ \\
\hline Silke Kern, MD & $\begin{array}{l}\text { Institute of } \\
\text { Neuroscience and } \\
\text { Physiology, } \\
\text { Sahlgrenska } \\
\text { Academy, University } \\
\text { of Gothenburg, } \\
\text { Sweden }\end{array}$ & $\begin{array}{l}\text { Interpreted the data, } \\
\text { revised the manuscript } \\
\text { for intellectual content }\end{array}$ \\
\hline
\end{tabular}

Appendix (continued)

\begin{tabular}{lll}
\hline Name & Location & Contribution \\
\hline $\begin{array}{l}\text { Lewis H. Kuller, } \\
\text { MD, DrPH }\end{array}$ & $\begin{array}{l}\text { Department of } \\
\text { Epidemiology, } \\
\text { Graduate School of } \\
\text { Public Health, } \\
\text { University of } \\
\text { Pittsburgh, PA }\end{array}$ & $\begin{array}{l}\text { Interpreted the data, } \\
\text { revised the manuscript } \\
\text { for intellectual content }\end{array}$ \\
& $\begin{array}{l}\text { Laboratory of } \\
\text { Epidemiology and }\end{array}$ & \\
\hline Penore Launer, & $\begin{array}{l}\text { Interpreted the data, } \\
\text { Population Sciences, } \\
\text { National Institute on }\end{array}$ & for intellectual content \\
& Aging, Bethesda, MD & \\
\hline Oscar L. Lopez & $\begin{array}{l}\text { Departments of } \\
\text { Neurology and } \\
\text { Psychiatry, University } \\
\text { of Pittsburgh, PA }\end{array}$ & $\begin{array}{l}\text { Interpreted the data, } \\
\text { revised the manuscript } \\
\text { for intellectual content }\end{array}$ \\
& & \\
\hline
\end{tabular}

Fiona E. Matthews, Institute of Health and

PhD

Society, Newcastle

revised the manuscript

upon Tyne, UK for intellectual content

\begin{tabular}{lll}
\hline Kevin McRae- & $\begin{array}{l}\text { Department of } \\
\text { Infectious Disease }\end{array}$ & $\begin{array}{l}\text { Interpreted the data, } \\
\text { revised the manuscript } \\
\text { Epidemiology, School }\end{array}$ \\
$\begin{array}{ll}\text { for intellectual content } \\
\text { of Public Health, } \\
\text { Imperial College } \\
\text { London, UK }\end{array}$
\end{tabular}

\begin{tabular}{lll}
\hline $\begin{array}{l}\text { Osorio Meirelles, } \\
\text { PhD }\end{array}$ & $\begin{array}{l}\text { Laboratory of } \\
\text { Epidemiology and } \\
\text { Population Sciences, } \\
\text { National Institute on } \\
\text { Aging, Bethesda, MD }\end{array}$ & $\begin{array}{l}\text { Analyzed and } \\
\text { interpreted the data, } \\
\text { revised the manuscript } \\
\text { for intellectual content }\end{array}$ \\
\hline $\begin{array}{l}\text { Thomas H. Mosley } \\
\text { Jr., PhD }\end{array}$ & $\begin{array}{l}\text { MiND Center, } \\
\text { University of } \\
\text { Mississippi Medical } \\
\text { Center, Jackson }\end{array}$ & $\begin{array}{l}\text { Interpreted the data, } \\
\text { revised the manuscript } \\
\text { for intellectual content }\end{array}$ \\
\hline
\end{tabular}

Matthew P. Pase, Boston University Interpreted the data,

PhD School of Medicine; the revised the manuscript

Framingham Heart for intellectual content

Study, MA; Melbourne

Dementia Research

Centre, The Florey

Institute for

Neuroscience and

Mental Health, Australia

\begin{tabular}{lll}
\hline Bruce M. Psaty, & Cardiovascular Health & Interpreted the data, \\
MD, PhD & Research Unit, & revised the manuscript \\
& Department of & for intellectual content
\end{tabular}

Medicine, University of

Washington, Seattle;

Departments of

Epidemiology and

Health Services,

University of

Washington; Kaiser

Permanente

Washington Health

Research Institute, Seattle

\begin{tabular}{lll}
\hline Claudia L. & $\begin{array}{l}\text { Boston University } \\
\text { Satizabal, PhD }\end{array}$ & $\begin{array}{l}\text { Interpreted the data, } \\
\text { revised the manuscript } \\
\text { Framingham Heart } \\
\text { for intellectual content }\end{array}$ \\
& Study, MA; The Glenn & \\
& Biggs Institute for & \\
Alzheimer's \& & \\
& Neurodegenerative \\
& Diseases, UT Health \\
& San Antonio, TX
\end{tabular}


Appendix (continued)

\begin{tabular}{lll}
\hline Name & Location & Contribution \\
\hline $\begin{array}{l}\text { Sudha Seshadri, } \\
\text { MD, DM }\end{array}$ & $\begin{array}{l}\text { Boston University } \\
\text { School of Medicine; the } \\
\text { Framingham Heart }\end{array}$ & $\begin{array}{l}\text { Interpreted the data, } \\
\text { revised the manuscrip } \\
\text { for intellectual content }\end{array}$ \\
& Study, MA; The Glenn & \\
& Biggs Institute for & \\
& Alzheimer's \& & \\
& Neurodegenerative & \\
& Diseases, UT Health & \\
& San Antonio, TX & \\
\end{tabular}

\begin{tabular}{ll}
\hline Ingmar Skoog, MD, & Institute of \\
PhD & Neuroscience and \\
& Physiology, \\
& Sahlgrenska Academy, \\
& University of \\
& Gothenburg, Sweden
\end{tabular}

\begin{tabular}{lll}
\hline Blossom C. M. & Institute of Health and & Interpreted the data, \\
Stephan, PhD & Society, Newcastle & revised the manuscript \\
& University, Newcastle & for intellectual content \\
& upon Tyne, UK &
\end{tabular}

\begin{tabular}{|c|c|c|}
\hline Hanna Wetterberg & $\begin{array}{l}\text { Institute of } \\
\text { Neuroscience and } \\
\text { Physiology, } \\
\text { Sahlgrenska Academy, } \\
\text { University of } \\
\text { Gothenburg, Sweden }\end{array}$ & $\begin{array}{l}\text { Interpreted the data, } \\
\text { revised the manuscript } \\
\text { for intellectual content }\end{array}$ \\
\hline Mei Mei Wong, PhD & $\begin{array}{l}\text { Department of } \\
\text { Infectious Disease } \\
\text { Epidemiology, School } \\
\text { of Public Health, } \\
\text { Imperial College } \\
\text { London, UK }\end{array}$ & $\begin{array}{l}\text { Interpreted the data, } \\
\text { revised the manuscript } \\
\text { for intellectual content }\end{array}$ \\
\hline $\begin{array}{l}\text { Anna Zettergren, } \\
\text { PhD }\end{array}$ & $\begin{array}{l}\text { Institute of } \\
\text { Neuroscience and } \\
\text { Physiology, } \\
\text { Sahlgrenska Academy, } \\
\text { University of } \\
\text { Gothenburg, Sweden }\end{array}$ & $\begin{array}{l}\text { Interpreted the data, } \\
\text { revised the manuscript } \\
\text { for intellectual content }\end{array}$ \\
\hline $\begin{array}{l}\text { Albert Hofman, } \\
\text { MD, PhD }\end{array}$ & $\begin{array}{l}\text { Harvard T.H. Chan } \\
\text { School of Public Health, } \\
\text { Boston, MA; Erasmus } \\
\text { MC, Rotterdam, the } \\
\text { Netherlands }\end{array}$ & $\begin{array}{l}\text { Designed and } \\
\text { conceptualized the } \\
\text { study, interpreted the } \\
\text { data, supervised } \\
\text { funding, and revised } \\
\text { the manuscript for } \\
\text { intellectual content }\end{array}$ \\
\hline
\end{tabular}

\section{References}

1. Global Burden of Disease Study Collaborators. Global, regional, and national incidence, prevalence, and years lived with disability for 301 acute and chronic diseases and injuries in 188 countries, 1990-2013: a systematic analysis for the Global Burden of Disease Study 2013. Lancet 2015;386:743-800.

2. Alzheimer's Disease International. Policy Brief for G8 Heads of Government: The Global Impact of Dementia 2013-2050 [online]. Available at: alz.co.uk/research/G8policy-brief. Accessed May 20, 2019.

3. WHO. First WHO Ministerial Conference on Global Action Against Dementia [Internet]. Available at: hoint $/$ mental_health/neurology/dementia/ministerial_ conference_2015_report/en/(2015). Accessed February 25, 2018.

4. Grasset L, Brayne C, Joly P, et al. Trends in dementia incidence: evolution over a 10 year period in France. Alzheimers Dement 2016;12:272-280.

5. Matthews FE, Stephan BC, Robinson L, et al. A two decade dementia incidence comparison from the Cognitive Function and Ageing Studies I and II. Nat Commun 2016;7:11398.

6. Roehr S, Pabst A, Luck T, Riedel-Heller SG. Is dementia incidence declining in high-income countries? A systematic review and meta-analysis. Clin Epidemiol 2018;10:1233-1247.
7. Satizabal CL, Beiser AS, Chouraki V, Chene G, Dufouil C, Seshadri S. Incidence of dementia over three decades in the Framingham heart study. New Engl J Med 2016; 374:523-532.

8. Schrijvers EM, Verhaaren BF, Koudstaal PJ, Hofman A, Ikram MA, Breteler MM. Is dementia incidence declining? Trends in dementia incidence since 1990 in the Rotterdam Study. Neurology 2012;78:1456-1463.

9. Larson EB, Yaffe K, Langa KM. New insights into the dementia epidemic. N Engl J Med 2013;369:2275-2277.

10. Chibnik LB, Wolters FJ, Backman K, et al. Trends in the incidence of dementia: design and methods in the Alzheimer Cohorts Consortium. Eur J Epidemiol 2017;32: 931-938.

11. Harris TB, Launer LJ, Eiriksdottir G, et al. Age, Gene/Environment SusceptibilityReykjavik study: multidisciplinary applied phenomics. Am J Epidemiol 2007;165: 1076-1087.

12. Dawber TR, Meadors GF, Moore FE, Jr. Epidemiological approaches to heart disease: the Framingham Study. Am J Public Health Nation's Health 1951;41: 279-281.

13. Feinleib M, Kannel WB, Garrison RJ, McNamara PM, Castelli WP. The Framingham offspring study: design and preliminary data. Prev Med 1975;4:518-525.

14. Bengtsson C, Blohme G, Hallberg L, et al. The study of women in Gothenburg 19681969: a population study: general design, purpose and sampling results. Acta Med Scand 1973;193:311-318.

15. Joas E, Guo X, Kern S, Ostling S, Skoog I. Sex differences in time trends of blood pressure among Swedish septuagenarians examined three decades apart: a longitudinal population study. J Hypertens 2017;35:1424-1431.

16. Dartigues JF, Gagnon M, Michel P, et al. The Paquid research program on the epidemiology of dementia: methods and initial results [in French]. Revue Neurol 1991; 147:225-230.

17. Grasset L, Matthews FE, Peres K, et al. Evolution of dementia diagnosis over time (1988-2013): evidence from French and English cohorts: implication for secular trends analyses. Alzheimers Dement 2018;10:490-497.

18. Hofman A, Brusselle GG, Darwish Murad S, et al. The Rotterdam Study: 2016 objectives and design update. Eur J Epidemiol 2015;30:661-708.

19. 3C Study Group. Vascular factors and risk of dementia: design of the Three-City Study and baseline characteristics of the study population. Neuroepidemiology 2003; 22:316-325.

20. McKhann GM, Knopman DS, Chertkow H, et al. The diagnosis of dementia due to Alzheimer's disease: recommendations from the National Institute on AgingAlzheimer's Association workgroups on diagnostic guidelines for Alzheimer's disease. Alzheimers Dement 2011;7:263-269.

21. Lin D, Wei L. The robust inference for the cox proportional hazards model. J Am Stat Assoc 1989;84:1074-1078.

22. Matthews FE, Arthur A, Barnes LE, et al. A two-decade comparison of prevalence of dementia in individuals aged 65 years and older from three geographical areas of England: results of the Cognitive Function and Ageing Study I and II. Lancet 2013; 382:1405-1412.

23. Alzheimer's Disease International. World Alzheimer Report 2015 [Internet]. Available at: alzcouk/research/world-report-2015. Accessed February 26, 2018

24. Fries JF. Aging, natural death, and the compression of morbidity. N Engl J Med 1980; 303:130-135

25. Members ECC, Brayne C, Ince PG, et al. Education, the brain and dementia: neuroprotection or compensation? Brain 2010;133:2210-2216.

26. Ohara T, Hata J, Yoshida D, et al. Trends in dementia prevalence, incidence, and survival rate in a Japanese community. Neurology 2017;88:1925-1932.

27. Li S, Yan F, Li G, et al. Is the dementia rate increasing in Beijing? Prevalence and incidence of dementia 10 years later in an urban elderly population. Acta Psychiatr Scand 2007;115:73-79.

28. Gao S, Ogunniyi A, Hall KS, et al. Dementia incidence declined in African-Americans but not in Yoruba. Alzheimers Dement 2016;12:244-251.

29. Noble JM, Schupf N, Manly JJ, Andrews H, Tang MX, Mayeux R. Secular trends in the incidence of dementia in a multi-ethnic community. J Alzheimers Dis 2017;60: 1065-1075.

30. Rajan KB, Weuve J, Barnes LL, Wilson RS, Evans DA. Prevalence and incidence of clinically diagnosed Alzheimer's disease dementia from 1994 to 2012 in a population study. Alzheimers Dement 2019;15:1-7.

31. Jones DS, Greene JA. The decline and rise of coronary heart disease: understanding public health catastrophism. Am J Public Health 2013;103:1207-1218.

32. Collaboration NCDRF. Trends in adult body-mass index in 200 countries from 1975 to 2014: a pooled analysis of 1698 population-based measurement studies with 19.2 million participants. Lancet 2016;387:1377-1396.

33. GBD 2016 Disease and Injury Incidence and Prevalence Collaborators. Global, regional, and national incidence, prevalence, and years lived with disability for 328 diseases and injuries for 195 countries, 1990-2016: a systematic analysis for the Global Burden of Disease Study 2016. Lancet 2017;390:1211-1259.

34. Collaboration NCDRF. Worldwide trends in blood pressure from 1975 to 2015: a pooled analysis of 1479 population-based measurement studies with 19.1 million participants. Lancet 2017;389:37-55. 


\section{Neurology}

Twenty-seven-year time trends in dementia incidence in Europe and the United States: The Alzheimer Cohorts Consortium

Frank J. Wolters, Lori B. Chibnik, Reem Waziry, et al.

Neurology 2020;95;e519-e531 Published Online before print July 1, 2020

DOI 10.1212/WNL.0000000000010022

This information is current as of July 1, 2020

\section{Updated Information \&} Services

References

Citations

Subspecialty Collections

Permissions \& Licensing

\section{Reprints}

including high resolution figures, can be found at: http://n.neurology.org/content/95/5/e519.full

This article cites 31 articles, 2 of which you can access for free at: http://n.neurology.org/content/95/5/e519.full\#ref-list-1

This article has been cited by 3 HighWire-hosted articles: http://n.neurology.org/content/95/5/e519.full\#\#otherarticles

This article, along with others on similar topics, appears in the following collection(s):

\section{All Cognitive Disorders/Dementia}

http://n.neurology.org/cgi/collection/all_cognitive_disorders_dementia Cohort studies

http://n.neurology.org/cgi/collection/cohort_studies

Incidence studies

http://n.neurology.org/cgi/collection/incidence_studies

Memory

http://n.neurology.org/cgi/collection/memory

Information about reproducing this article in parts (figures,tables) or in its entirety can be found online at:

http://www.neurology.org/about/about_the_journal\#permissions

Information about ordering reprints can be found online:

http://n.neurology.org/subscribers/advertise

Neurology ${ }^{\circledR}$ is the official journal of the American Academy of Neurology. Published continuously since 1951, it is now a weekly with 48 issues per year. Copyright Copyright @ 2020 The Author(s). Published by Wolters Kluwer Health, Inc. on behalf of the American Academy of Neurology.. All rights reserved. Print ISSN: 0028-3878. Online ISSN: 1526-632X.

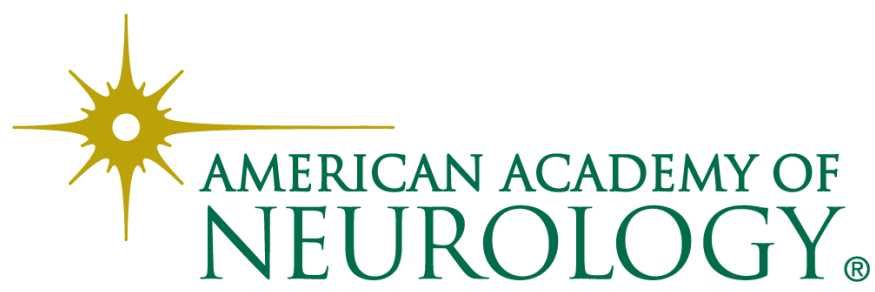

